\title{
Research on Creative and Applied Talents Training Program for Engineering Management Specialty under the Background of Engineering Education Certification
}

\author{
Mo Liu ${ }^{1, a}$ and Yuxia Zhong ${ }^{2, b^{*}}$ \\ ${ }^{1}$ Aotomotive and Architectural Engineering Institute, Beihua University, China,130021 \\ ${ }^{2}$ Aotomotive and Architectural Engineering Institute, Beihua University, China, 130021 \\ a447206129@qq.com, b413389929@qq.com \\ * The Corresponding Author
}

\begin{abstract}
Keywords: Engineering education certification; Talent training goal; Graduation requirements; Optimization of curriculum system

Abstract. According to characteristics of the local economy and the "civil" reality needs, this paper revises the professional training goal of the new training program version 2018 in engineering management personnel and remolds our graduate specifications by 12 graduates of engineering education accreditation requirements. Finally, optimizes curriculum system in the light of experts' argument and integrating related subjects.
\end{abstract}

\section{Introduction}

Engineering education accreditation is a quality certification of higher education for related subjects of engineering technology fields by engineering industry association and engineering practitioners. This accreditation is a process that ensures the employees' ability of the engineering industry reaching a certain level, and it is also an international quality assurance system of engineering education.

In June 2013, China became a preparatory member of the Washington Agreement, marking China's engineering education professional certification step into a substantive implementation stage. In March 2015, China Engineering Education Professional Certification Association revised the "engineering education accreditation standard" (2015 Edition), which is composed of two parts: general standard and professional supplementary standard. Among them, the general standard includes 7 elements, namely, students, training objectives, graduation requirements, continuous improvement, curriculum system, teaching staff and support conditions, while professional supplementary standards specifies the special requirements of relevant majors in curriculum system, teaching staff and support conditions. Professional certification advocates the cultivation of international talents and the pursuit of international comparability and equivalence. Compared with the evaluation of the undergraduate teaching level, it has the characteristics of international equivalence, target orientation, ability oriented, and continuous improvement.

\section{The Purpose of Research}

Based on the characteristics of local economy, the realistic demand of "big civil engineering", referring to the professional accreditation standard, and on the basis of defining the knowledge, ability and quality system of engineering management professionals and positioning their training objectives, we attend to solved the following problems:

Redefining the target of cultivating talent in the background of enterprises and the guide of demand.

Distinguishing the requirements of knowledge, ability and quality of engineering management professionals, according to the different social needs of the applied undergraduate type schools.

Reformulating graduation specifications and optimizing the curriculum system and the construction of the content on the basis of 12 graduate requirements of the project certification. 
Highlighting out efforts on practice reform, in the carrier of real projects.

Reforming the teaching contents and methods of the curriculum to realize training of talents meets the demand of the market seamlessly.

Getting through the first, second, third classroom to fully realize the requirements for the awareness of innovation in the evaluation system.

\section{Revise the Training Program}

\section{Demand Analysis of Talents Needed for Industry Enterprises}

Our school emphasizes the training of practical talents, and the practical talents must adapt to the needs of industry and enterprises. Social needs analysis can be comprehensively analyzed from the aspects of current domestic and international economic situation, professional development direction, labor market supply and demand, talent requirements of professional post group and industry development trend. Specifically, we can carry researches on the industry, conduct interviews with industry experts to get the industry needs of enterprises; at the same time, we should pay a return visit to graduates to acquaint their feelings of training talents and jobs, this is also an important factor for revising program. Graduates, as "works" of former training program, their feedbacks are the best.

\section{Determine the Goal of Personnel Training}

On the basis of the analysis of social demand, we should convert demand to the goal of talents training. The training goal of new training program engineering management professionals in the 2018 edition has been revised as follows: we should train the versatile senior managers, which should be all-around of morality to meet socialism modernize build of China, grasp the technical knowledge in the field of architecture and civil engineering, and grasp the basic knowledge of management, economy and law related to engineering management, be higher professional and strong project management ability, economic analysis and application of BIM technology, occupy morals, spirit of innovation and international perspective, compound senior management in the whole life cycle engineering management in the field of building and civil engineering .

Professional graduates can apply for registration of construction engineers, registered cost engineers and other national practicing qualifications, and be able to engage in engineering project management, teaching and research work in design, construction, supervision, consulting and other enterprises and government departments.

\section{Determine the Students' Graduation Requirements and to List the Abilities That Students Should Have When They Graduate}

After determining the goal of talents training, the goal of training the talents is specific to the knowledge, ability and quality that the students should have when they graduate. The requirements of graduates from the standard of engineering education certification should be fully covered in the following contents:

Engineering knowledge: mathematics, natural science, engineering foundation and professional knowledge can be used to solve complex engineering problems.

Problem analysis: can apply the basic principles of mathematics, natural science and Engineering Science to identify, express and analyze complex engineering problems through literature research, so as to get effective conclusions.

Design or development solutions: be able to design solutions solve complex engineering problems, and to design a system to meet the specific needs of the system, the unit (or components) process, and reflect the sense of innovation in the design process, considering the social, health and safety, legal, cultural and environmental factors.

Research: could do research on complex problem with scientific principles an scientific methods, including designing experiments, analyzing and interpreting data, and obtaining reasonable and effective conclusions through information integration.

Use modern tools: can develop, select and use appropriate technologies, resources, modern engineering tools and information technology tools to solve complex engineering problems, including prediction and simulation, at the same time understand their limitations. 
Engineering and society: can make reasonable analysis based on engineering related background knowledge, evaluate the impact of professional engineering practice and complex engineering problem solving on society, health, safety, law and culture, and understand the responsibilities that should be undertaken.

Environment and sustainable development: the ability to understand and evaluate the impact of professional engineering practice on the environmental and social sustainable development of complex engineering problems.

Professional norms: have scientific literacy and social responsibility of humanities, and can understand and abide by professional ethics and norms in engineering practice and fulfill responsibilities.

Individuals and teams: assume the roles of individuals, team members, and leaders in a multidisciplinary team.

Communication: effectively communicate with the industry colleagues and the public on complex engineering problems, including writing reports and design manuscripts, presenting statements, clearly expressing or responding to instructions. Having a certain international perspective and can communicate in the cross-cultural background.

Project management: understand and master the engineering management principles and economic decision-making methods, besides, can be applied in the multidisciplinary environment.

Lifelong learning: the consciousness of autonomous learning and lifelong learning, the ability to continue to learn and adapt to development.

Integrating related subjects and optimizing the curriculum system based on the requirements of professional standards and professional evaluation.

Based on the Above Understanding, in the 2018 Project Management Personnel in the New

\section{Revision of the Scheme}

Our institute takes the engineering education accreditation standard, professional standard and supplementary civil engineering management professional evaluation standards as the guidance, communicates with industry enterprises, analysis China registered engineer occupation, with the training goal and market demand of definition of practical university, determines the professional orientation of Engineering Management in application oriented universities and training objectives. At the same time, we continue to learn from the experience of professional evaluation of colleges and universities, and continue to improve the training program with applied characteristics. The "modular" curriculum system based on "platform courses" is built to reflect the requirements of elastic learning. The whole curriculum system is divided into four modules, namely, general education, interdisciplinary basic courses, basic courses of this subject and course of professional direction. The curriculum of engineering management and the allocation of credits are detailed in Table 1.

Table 1 The form of teaching hours (credits) in the course

\begin{tabular}{|c|c|c|c|c|}
\hline Curriculum category & credit & $\begin{array}{c}\text { Percentage } \\
\text { of } \\
\text { total credit }\end{array}$ & Hours & Percentage of total school hours \\
\hline General Education Required Subjects & 78 & $30.53 \%$ & 720 & $32.37 \%$ \\
\hline General Education Elective Subjects & 6 & $2.35 \%$ & 96 & $4.32 \%$ \\
\hline $\begin{array}{c}\text { Compulsory course of interdisciplinary } \\
\text { Foundation }\end{array}$ & 54 & $21.14 \%$ & 344 & $15.47 \%$ \\
\hline Interdisciplinary basic elective course & 2.5 & $0.98 \%$ & 40 & $1.80 \%$ \\
\hline Basic courses of this subject & 71 & $27.79 \%$ & 584 & $26.26 \%$ \\
\hline Basic Elective Course in this subject & 6 & $2.35 \%$ & 96 & $11.87 \%$ \\
\hline Compulsory course of discipline specialty & 33 & $12.92 \%$ & 264 & $3.60 \%$ \\
\hline Course elective course & 5 & $1.96 \%$ & 80 & $100 \%$ \\
\hline Total & 255.5 & $100 \%$ & 2224.0 & \\
\hline
\end{tabular}

Carry out the Expert Argument of the Talent Training Program 
After founding the construction of the curriculum system, the talent training plan is basically completed. At this time, we need to hire experts from on and off campus and experts from the industry to demonstrate the talent training plan. The scope of argumentation focuses on whether the training objectives of talents training are correct, whether students' knowledge, ability and quality are in line with training objectives, whether the relationship between ability structure and curriculum system is appropriate, that is, whether courses can achieve capacity training.

\section{Acknowledgements}

\section{Research Subject in Education and Teaching of Beihua University(number XJYB2017001)}

Research and practice of innovative applied talents training program oriented to engineering management under the background of Engineering Education Certification

\section{Education Fund Project of the Education Department of Jilin Province}

Dual-Invasion Application of Civil Engineering under the Background of College Entrance Examination Reform Research and Practice on the Model of Talent Training Mode (2017 Jijiao High SJJY201711)

Research on the Characteristics and Education System of Civil Engineering Dual-Innovation Applied Talents in the "Internet+" Era (2016 Jijiao High-32 SGJY201609);

\section{References}

[1] Han Yang:Journal of Wuyi University, Vol. 35 (2016) No.3, p.107.

[2] Information on http://ceeaa.heec.edu.cn/. 